I6 a 18 de outubro de 2019 - Campinas | Brasil

\title{
La Gran Via: a zarzuela espanhola que modernizou a dramaturgia brasileira
}

\author{
Carolina Fernandes de Melo*, Orna Messer Levin.
}

\begin{abstract}
Resumo
Esse trabalho tem por objetivo estudar a circulação da zarzuela no Brasil, desde a primeiras tentativas de implantar o gênero dramático no país, feitas pelo músico e compositor José Zapata y Amat, até o ponto que marcou seu auge, com La Gran Via, considerada pelos críticos teatrais, como Artur Azevedo, a maior zarzuela de todos os tempos. Busca-se trilhar o caminho de difusão da zarzuela no Brasil, que alcançou o patamar de enorme popularidade no final do século XIX, mas foi completamente esquecida. Apesar do apagemento de sua importância histórica, a zarzuela ajudou a modernizar a dramaturgia brasileira.
\end{abstract}

\section{Palavras-chave:}

Teatro espanhol, zarzuela, La Gran Vía

\section{Introdução}

Compreender a contribuição do teatro espanhol ao Brasil é um desafio. Os gêneros teatrais típicos da Espanha, que fizeram tanto sucesso nos palcos brasileiros, são hoje pouco estudados. A zarzuela é um exemplo da dramaturgia esquecida, apesar da importância que teve no século XIX. Buscou-se conhecer os aspectos históricos de sua circulação no país, traçando uma cronologia, que parte da criação do gênero para entender o sucesso obtido nos palcos brasileiros.

Procurou-se identificar as transformações pelas quais a zarzuela espanhola passou para atingir tal sucesso e conhecer os temas abordados pelos autores. Realizou-se um levantamento de peças originais, traduções e encenações junto às fontes primárias disponíveis na Hemeroteca Digital Brasileira. O objetivo foi identificar os títulos mais encenados, conhecer as companhias teatrais e os tradutores, a fim de perceber como as zarzuelas foram adaptadas e se mantiveram em cartaz por longo período nos palcos brasileiros.

A pesquisa se voltou ao estudo do caso particular de $L a$ Gran Vía, zarzuela muito aclamada pelos críticos teatrais. Buscou-se entender como a peça impactou a maneira com que se fazia teatro no final do século XIX.

\section{Resultados e Discussão}

Apesar de a zarzuela ser um gênero datado do século XVII, cujo primeiro autor foi Calderón de la Barca, ela sofreu muitas alterações até chegar aos teatros líricos nacionais, nas décadas de 1850 e 1860. Nesse processo, houve a incorporação de temas urbanos. Quando passou a integrar o repertório lírico nacional, a zarzuela, segundo Heller-Lopes, foi uma das referências que inaugurou a cultura operística no Brasil, ao lado das óperas italianas.

A introdução da zarzuela no país resulta das muitas tentativas do compositor José Zapata y Amat de estabelecer o gênero lírico no teatro nacional. Na década de 1870, muitas companhias espanholas de zarzuelas vieram ao Brasil. Elas encenavam o repertório original em espanhol. A ação dramática ainda não era adaptada para o espaço brasileiro. A situação se modificará na década seguinte. Impulsionados pelo sucesso da zarzuela, autores e companhias brasileiras passaram a traduzir e encená-las. Nesse contexto, estreou A Grande Avenida, tradução de La Gran Vía, escrita em 1886 por Pérez y Gozáles, e música de Chueca e Valverde, no dia 23 de dezembro de 1887, pela companhia de Dias Braga.
A revista madrileña cómico-lírica é apontada pelo crítico Artur Azevedo como uma das maiores zarzuelas de todos os tempos.

Figura 1. Anúncio de representação de $A$ Grande Avenida no Teatro Recreio Dramático, tradução de La Gran Vía, no dia 23 de dezembro de 1887

THEATRO RECBEIO DRAMATICO

COMPANHIA DRAMATICA-EMPREZA DIAS BRAGA

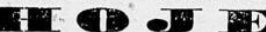

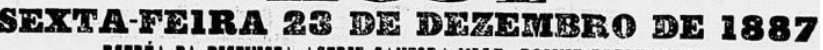

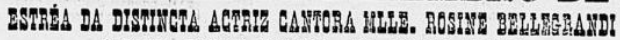

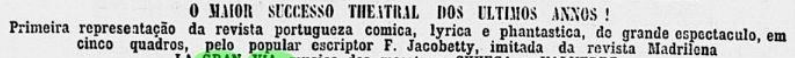

\section{A GRANDE AVENIDA}

\section{Conclusões}

A zarzuela exerceu um grande impacto no teatro nacional. La Gran Vía trouxe uma mudança significativa no modo de encarar a temática urbana no teatro cômicolírico.

É possível apontar uma aproximação direta com a peça brasileira A Capital Federal, de Artur Azevedo. Tal proximidade se evidencia nos temas abordados, nos tipos retratados, nas personagens e nos problemas ligados ao processo de urbanização das capitais.

\section{Agradecimentos}

Agradeço à professora Orna Levin, que tem ajudado a desenvolver a pesquisa, à Pró Reitoria de Pesquisa e ao CNPq pela oportunidade de ter desenvolvido o projeto "A presença de zarzuelas nos palcos brasileiros nos anos finais do século XIX e início do XX (1880 a 1914)" ao longo do segundo semestre de 2018.

AZEVEDO, Arthur. O theatro: crônicas de Arthur Azevedo (1894-1908) Organização Larissa de Oliveira Neves, Orna Messer Levin. Campinas, SP: Editora da Unicamp, $2009 . \quad$. A Capital Federal. Rio de Janeiro, RJ: Record, 2001.

CHUECA, Frederico, VALVERDE, Joaquín, PÉREZ Y GONZÁLES,

Felipe. La Gran Vía, 27 ${ }^{\mathrm{a}}$ ed. Madrid: R. Velasco, 1910. Disponível em: https://archive.org/details/lagranvarevist00chue. Acesso em julho de 2019. DIÁRIO DE NOTÍCIAS, 1887.

HELLER-LOPES, André. (1857-1863): music, society and the birth of Brazilian opera in nineteenth-century Rio de Janeiro. Tese de doutorado King's College London (University of London). Londres, 2010. Disponível em: https://ethos.bl.uk/OrderDetails.do?uin=uk.bl.ethos.560575. Acesso em fevereiro de 2019.

PLAZA, Sixto. La zarzuela, género olvidado o malentendido. In: Hispania, Vol. 73, No. 1 (Mar., 1990), pp. 22-31. Disponível em: http://www.jstor.org/stable/342956. Acesso em junho de 2018. 